\title{
The Spectrum of Gastroenteritis at the Pediatric Outpatient Clinic, Department of Child Health, School of Medicine, University of North Sumatera in 1982
}

\author{
by \\ TAHENG SEBA YANG, ATAN BAAS SINUHAJI, TYAHAYA BANGUN, \\ MANIHAR D. MARBUN and A.H. SUTANTO
}

(From the Department of Child Health, School of Medicine, University of North Sumatera, Pirngadi Hospital, Medan)

\begin{abstract}
The number of children attending the Pediatric Outpatient Clinic of Pirngadi Hospital, Medan, during 1982 was 15.375. Out of these, I246 (8.10\%) had gastroenteritis. Most of the patients (1046 or 83.94\%) were under two years old. The male to female ratio was 1.6: 1. The peak incidence for attendance was in January, April, and May. Of 1057 patients under five years old, 383 (36.2\%) also had malnutrition. The highest percentage $(70.75 \%)$ of those who had malnutrition was found in the I to 2 years age group. Of 370 palients whose Hb level was examined, $185(50 \%)$ had anemia. The highest percentage (67.02\%) was in the below l year group. Only 360 (28.8\%) of gastroenteritis cases received oral rehydration solution. There were 23 (1.85\%) cases in which diarrhea lasted longer than 7 days.

The number of patients admitted to the ward was $213(17.07 \%)$, and the highest percentage was in the above 3 years age group. The largest number of hospitalized patients was in Jamury (43), February (21), and April (28); while the highest percentage was in April (20.40\%), June (21.42\%) and August (31.42\%).

Peak rainfall in Medan during 1982 was in October, November, and December, i.e. much $322.2 \mathrm{~mm}, 366.4$ and $382 \mathrm{~mm}$, respectively.
\end{abstract}




\section{Introduction}

Until now gastroenteritis still ranks the second in children morbidity after URI at the Pediatric OPC of several medical centers (Bishop, 1985; Gracey, 1978; Morley, 1979; Rowland, 1980; Tumbelaka, 1979), because of a number of predisposing factors which can influence the incidence of diarrhea (Bishop, 1985; Lanzkowsky et al., 1985; Lubis Iskandar et al., 1984; Morley 1979; Rowland, 1978; Suharyono et al. 1978)

Some authors have reported the incidence of gastroenteritis in many Pediatric OPC of several hospitals in Medan from 1960 to 1983 ranging from 7.67 - 14.90\% (Hamid et al., 1982; Jo, 1965; Lubis et al., 1979; Nasution et al., 1981; Sinuhaji et al., 1984; Sufriar et al., 1982; Tarigan et al., 1968).

The aim of this study is to observe the spectum of gastroenteritis in children attending the Pediatric OPC of Pirngadi Hospital, Medan, during 1982.

\section{Materials and Methods}

1. The study was made retrospectively by

2. The diagnosis of gastroenteritis was

3. The recording included: the number of collecting all patients' records who came to the Pediatric OPC of Pirngadi Hospital, Medan, during 1982. made when the child passed watery stool with the frequency of more than three times, with or without vomiting. Patients with repeat visit after the previous episode had recovered, were recorded as new attendants. Patient with marked bloody stool were excluded. attendants, the number of patients and under-fives with gastroenteritis, sex, associated diseases (malnutrition and anemia), number of hospitalized pa-

tients, ORS receivers, the frequency of episode of diarrhea per year and rainfall.

4. Nutritional state was determined according to 'KMS' (Dep. Kes. RI 1975).

5. Anemia was diagnosed according to the WHO criteria; for children under 6 years, $\mathrm{Hb}$ level less than $11 \mathrm{gr} \%$ and for children 6 to 14 years old, Hb level less than $12 \mathrm{gr} \%$ (Chai et al., 1969).

6. Prolonged diarrhea was diagnosed if diarrhea lasted longer than 7 days, chronic diarrhea was diagnosed when the diarrhea lasted longer than 14 days.

7. Data on rainfall was obtained from the Meteorology Geophisics Station Medan during 1982

\section{Result}

1. a. The number of attendants at the OPC Pediatric of Pirngadi Hospital during 1982 were 15.375 , and $1246(8.10 \%)$ of them had gastroenteritis. The largest number were found in January, 226; April, 137 and May, 131. The highest percentage was found in January, 226 and May $131(9.18 \%)$

b. The number of patients was 1110 1057 of them were under fives (Fig. 1). (13.67\%); March, 128 (10.15\%)

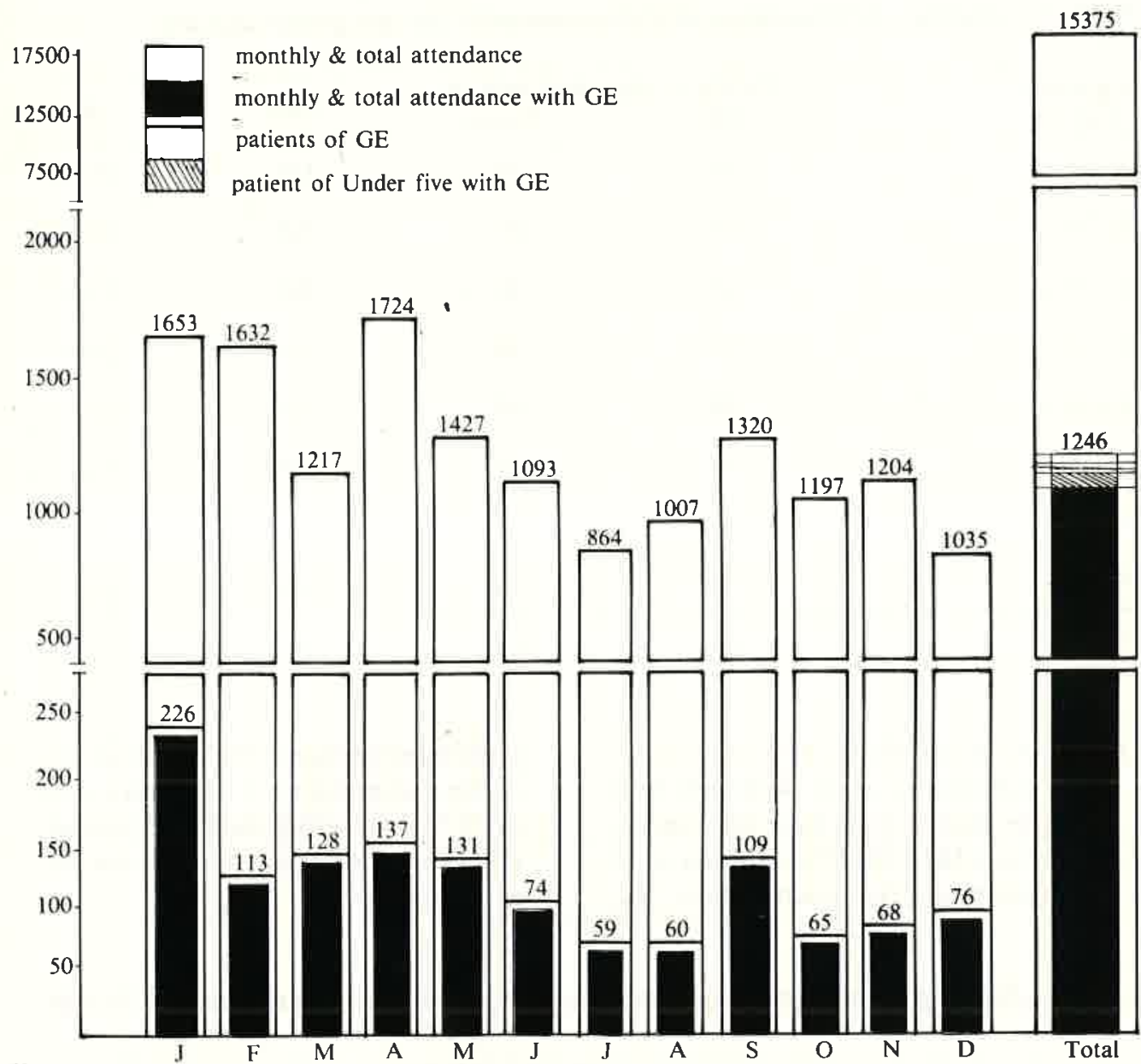

Fig. 1 : Total and monthly attendance with gastroenteritis and the number of patients and under fives as the Pediatric OPC of Pirngadi Hospital, Medan, during 1982

2. Most of the attendants with gastroenteritis ( 1046 or $83.94 \%$ ) were under two years old and $781(62.68 \%)$ were under one year old. Most of the attendants with gastroenteritis $(268$ or
$34.30 \%$ ) aged under one year, were of the age group of 3 to 6 months. Male patient were more than female (696: 550), see Table 1 . 
Table 1 : Number of attendants with gastroenteritis by age group and sex

\begin{tabular}{|c|c|c|c|c|}
\hline \multirow{2}{*}{$\begin{array}{r}\text { Age group } \\
\text { (Months) }\end{array}$} & \multicolumn{2}{|c|}{ Number of Attendants with GE } & \multirow[b]{2}{*}{ Total } & \multirow[b]{2}{*}{$\%$} \\
\hline & Male & Female & & \\
\hline $0-3$ & 92 & 44 & 136 & 17.40 \\
\hline $3-6$ & 167 & 101 & 268 & 34.30 \\
\hline $6-9$ & 115 & 85 & 200 & 25.60 \\
\hline $9-12$ & 108 & 69 & 177 & 22.70 \\
\hline $0-12$ & 482 & 299 & 781 & 62.68 \\
\hline $12-24$ & 99 & 166 & 265 & 21.26 \\
\hline $24-36$ & 40 & $31 !$ & 71 & 5.69 \\
\hline $36>$ & 75 & 54 & 129 & 10.37 \\
\hline Total & 696 & 550 & 1246 & \\
\hline
\end{tabular}

3. The 1246 attendants with gastroenteritis consisted of the 1110 patients with gastroenteritis; there were 1057 underfives and $383(36.23 \%)$ of them were

highest percentage of malnutrition was in the age group of 1 to 2 years (150 or $70.75 \%$ ) of which the larger number (191) was in the group of under one year (Table 2).

Table 2 : Number of malnutrition in the under five patients with gastroenteritis by age

\begin{tabular}{|c|c|c|c|}
\hline \multirow{2}{*}{$\begin{array}{l}\text { Age group } \\
\text { (Years) }\end{array}$} & \multicolumn{2}{|c|}{ Number of Patients } & \multirow{2}{*}{$\%$} \\
\hline & Gastroenteritis & $\begin{array}{l}\text { Gastroenteritis with } \\
\text { Malnutrition }\end{array}$ & \\
\hline $0-1$ & 714 & 191 & 26.75 \\
\hline $1-2$ & 212 & 150 & 70.75 \\
\hline $2-3$ & 65 & 31 & 47.69 \\
\hline $3-4$ & 34 & 6 & 17.65 \\
\hline $4-5$ & 32 & 5 & 15.62 \\
\hline Total & 1057 & 383 & 36.23 \\
\hline
\end{tabular}

4. Of the 191 gastroenteritis patients with malnutrition aged under one year, the

highest percentagè of malnutrition (55 or $82.08 \%$ ). was in the age group 11 to 12 months (Fig. 2)

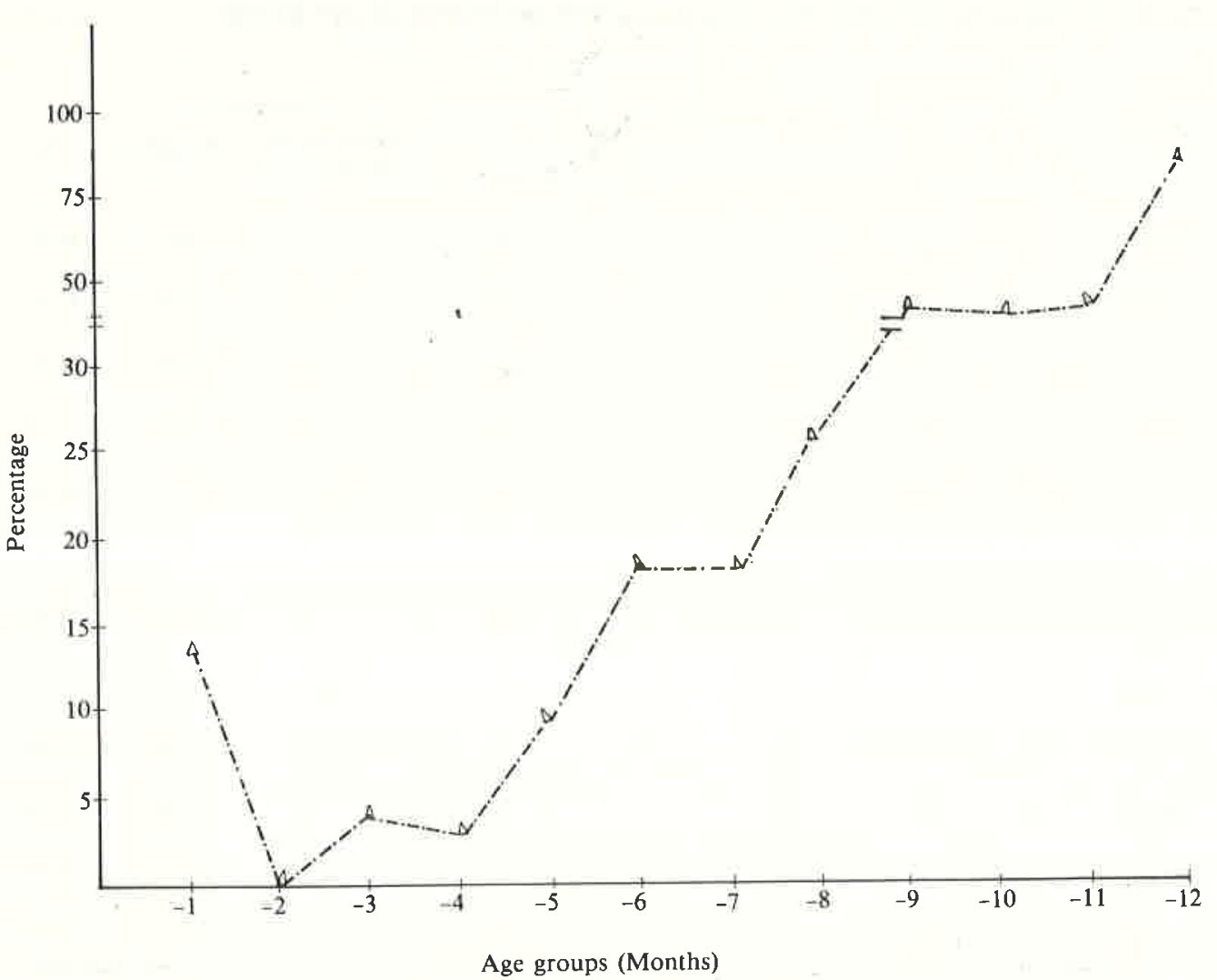

Fig. 2: Percentage of malnutrition in patients with gastroenteritis aged under one year according to age group

5. Of the 1246 attendants with gastroenteritis, $231(17.07 \%)$ were hospitalized. The largest number of children hospitalized was in January, (43) and February, (21); while the highest percentage was in April, (28 or $20.40 \%$ ); June (18 or $21.42 \%$ ) and August
(19 or $31.14 \%$ ). The highest percentage of hospitalized patients according to age group was in the above 3 years, i.e. 44 patients $(34.10 \%)$ out of 129 attendants. In the age group of under one year there were 119 patients $(15.23 \%)$ of 781 attendants (Table 3). 
Table 3 : Number of monthly hospitalization according to age group

\begin{tabular}{|c|c|c|c|c|c|c|c|}
\hline \multirow{2}{*}{ Month } & \multicolumn{4}{|c|}{ Age group (Years) } & \multicolumn{2}{|c|}{ Number of } & \multirow[b]{2}{*}{$\%$} \\
\hline & $0-1$ & $1-2$ & $2-3$ & $>3$ & $\begin{array}{l}\text { Hospitalized } \\
\text { children }\end{array}$ & Attendants & \\
\hline January & 19 & 5 & 5 & 14 & 43 & 226 & 19.02 \\
\hline February & 13 & 5 & - & 3 & 21 & 123 & 17.07 \\
\hline March & 6 & 3 & 1 & 12 & 12 & 128 & 9.37 \\
\hline April & 16 & 7 & 1 & 4 & 28 & 137 & 20.40 \\
\hline M a y & 12 & 2 & - & 2 & 16 & 131 & 12.20 \\
\hline J u n e & 8 & 3 & - & 7 & 18 & 84 & 21.42 \\
\hline $\mathrm{J}$ u 1 y & 5 & 3 & - & - & 8 & 62 & 12.90 \\
\hline August & 12 & 3 & - & 14 & 19 & 61 & 31.41 \\
\hline September & 8 & 4 & - & 1 & 13 & 119 & 10.09 \\
\hline October & 6 & 2 & - & 1 & 9 & 68 & 13.20 \\
\hline November & 6 & 4 & - & 2 & 12 & 72 & 16.66 \\
\hline December & 8 & 1 & 1 & 4 & 14 & 79 & 17.72 \\
\hline $\begin{array}{l}\text { Total hospi- } \\
\text { talized children }\end{array}$ & 119 & 42 & 8 & 44 & 213 & & \\
\hline $\begin{array}{l}\text { Total atten- } \\
\text { dants }\end{array}$ & 701 & 265 & 71 & 129 & & 1246 & \\
\hline$\%$ & 15.23 & 15.80 & 11.26 & 34.10 & & & 17.07 \\
\hline
\end{tabular}

6. The highest percentage of hospitalized patients of the 119 patients under one year old was in the age gnoup of below
1 month (17 out of 48 or $38.63 \%$ ) and in the age group of $10-11$ months (16 out of 57 or $28.07 \%$ ) (Table 4 ).
Table 4 : Number and percentage of hospitalized patients under one year of age based on month age group

\begin{tabular}{cccc}
\hline $\begin{array}{c}\text { Age groups } \\
\text { (Months) }\end{array}$ & Attendants & Nospitalized children & \\
\hline $0-1$ & 44 & 17 & 36.83 \\
$1-2$ & 43 & 6 & 13.95 \\
$2-3$ & 49 & 2 & 4.08 \\
$3-4$ & 92 & 8 & 8.69 \\
$4-5$ & 95 & 7 & 7.36 \\
$5-6$ & 81 & 10 & 19.75 \\
$6-7$ & 81 & 12 & 14.81 \\
$7-8$ & 58 & 10 & 17.24 \\
$8-9$ & 61 & 13 & 21.31 \\
$9-10$ & 51 & 8 & 15.68 \\
$10-11$ & 57 & 16 & 28.07 \\
$11-12$ & 69 & 4 & $5.79)$ \\
\hline Total & 781 & 119 & 15.23
\end{tabular}

7. Of 1246 attendants with gastroenteritis, in $\mathbf{3 7 0}$ the hemoglobin level was

$(50 \%)$ suffered from anemia. The highest percentage was in the below one examined. Of the 370 children, 185 year old $(126$ or $67.02 \%)$. (Table 5 ).

Table 5 : Number of attendants of gastroenteritis suffering from anemia by age group

\begin{tabular}{ccccc}
\hline $\begin{array}{c}\text { Age group } \\
\text { (Years) }\end{array}$ & Attendants & $\begin{array}{c}\text { Examined } \\
\text { Hb level }\end{array}$ & $\begin{array}{c}\text { Number of patients } \\
\text { with anemia }\end{array}$ & $\%$ \\
\hline-1 & 781 & 280 & 126 & 67.02 \\
-2 & 265 & 42 & 39 & 59.37 \\
-3 & 71 & 38 & 12 & 22.4 \\
$>3$ & 129 & 20 & 8 & 13.33 \\
\hline Total & 1246 & 370 & 185 & 50.00 \\
\hline
\end{tabular}


8. Of 1246 attendants with gastroenteritis only $360(28.90 \%)$ received ORS ("Table 6).

Table 6 : Number of attendants with gastroenteritis receiving OR 5 by age group

\begin{tabular}{lccc}
\hline $\begin{array}{c}\text { Age group } \\
\text { (Years) }\end{array}$ & $\begin{array}{c}\text { Attendants with } \\
\text { Gastroenteritis }\end{array}$ & $\begin{array}{c}\text { ORS } \\
\text { Receivers }\end{array}$ & $\%$ \\
\hline $0-1$ & 781 & 243 & 31.10 \\
$1-2$ & 265 & 74 & 27.90 \\
$2-3$ & 71 & 20 & 28.20 \\
$>3$ & 129 & 23 & 28.80 \\
\hline T o t a l & 1246 & 360 & 28.90 \\
\hline
\end{tabular}

9. The 1246 attendants with gastroenteritis during 1982 comprised 1110 patients, of 996 patients of them with

episode of diarrhea 1 time/year; 96 patients 2 times/years; 18 patients times/years and 2 patients 4 times/ years (Table 7).

Table 7 : Number of episode of diarrhea in each patient per year

\begin{tabular}{cccc}
\hline $\begin{array}{c}\text { Episodes of diarrhoea } \\
\text { per year }\end{array}$ & $\begin{array}{c}\text { Number of } \\
\text { patients }\end{array}$ & $\begin{array}{c}\text { Number of } \\
\text { attendants }\end{array}$ & $\%$ \\
\hline $\mathrm{x}$ & 996 & 996 & 89.73 \\
$2 \mathrm{x}$ & 94 & 188 & 8.45 \\
$3 \mathrm{x}$ & 18 & 54 & 1.62 \\
$4 \mathrm{x}$ & 2 & 8 & 0.8 \\
\hline T o t a 1 & 1110 & 1246 & \\
\hline
\end{tabular}

10. Of 1246 attendants with gastroenteritis, only $23(1.80 \%)$ suffered from diarrhea for more than 7 days and none had diarrhea for more than 14 days (Table 8).
Table 8 : Number of patients with gastroenteritis with prolonged and chronic diarrhea

\begin{tabular}{lccccc}
\hline $\begin{array}{c}\text { Age group } \\
\text { (years) }\end{array}$ & $\begin{array}{c}\text { Number of attendants } \\
\text { with gastroenteritis }\end{array}$ & $\begin{array}{c}\text { Prolonged } \\
\text { diarrhoea }\end{array}$ & $\begin{array}{c}\text { Chronic } \\
\text { diarrhoea }\end{array}$ & $\%$ & $\%$ \\
\hline $0-1$ & 781 & 20 & 2.60 & - & - \\
$1-2$ & 265 & 2 & 0.65 & - & - \\
$2-3$ & 71 & 1 & 1.40 & - & - \\
$>3$ & 129 & & & & - \\
\hline Total & 1246 & 23 & 1.84 & - \\
\hline
\end{tabular}

11. During 1982 an increase in percentage of gastroenteritis cases at the OPC for sick children of Pirngadi Hospital, Me-

dan was seen in January, March and May, when rainfalls decreased. (Fig 3).

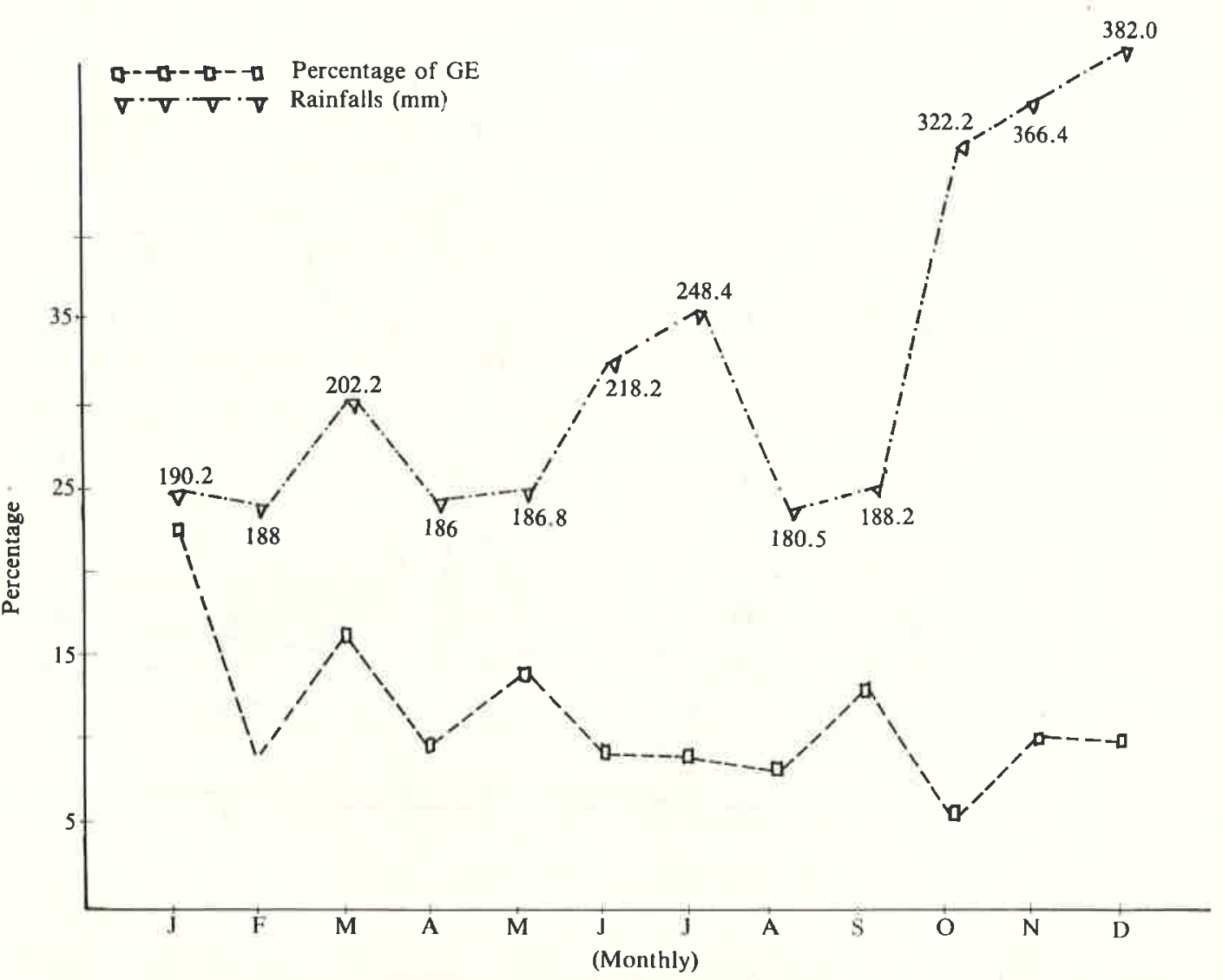

Fig. 3 : Percentage of attendants with gastroenteritis per month according to the average of the rainfalls during 1982 at the Pediatric OPC Pirngadi Hospital Medan 
12. The highest percentage of patients who were hospitalized by age group were as follows: (a) Age group 0 to 1 year, in April and August, i.e. $18.20 \%$ and $35.30 \%$, respectively; (b) Age group 1 to 2 years, in April, August and October, i.e. $20 \%, 30 \%$ and $20 \%$, respectively; (c) Age group 2 to 3 years, in

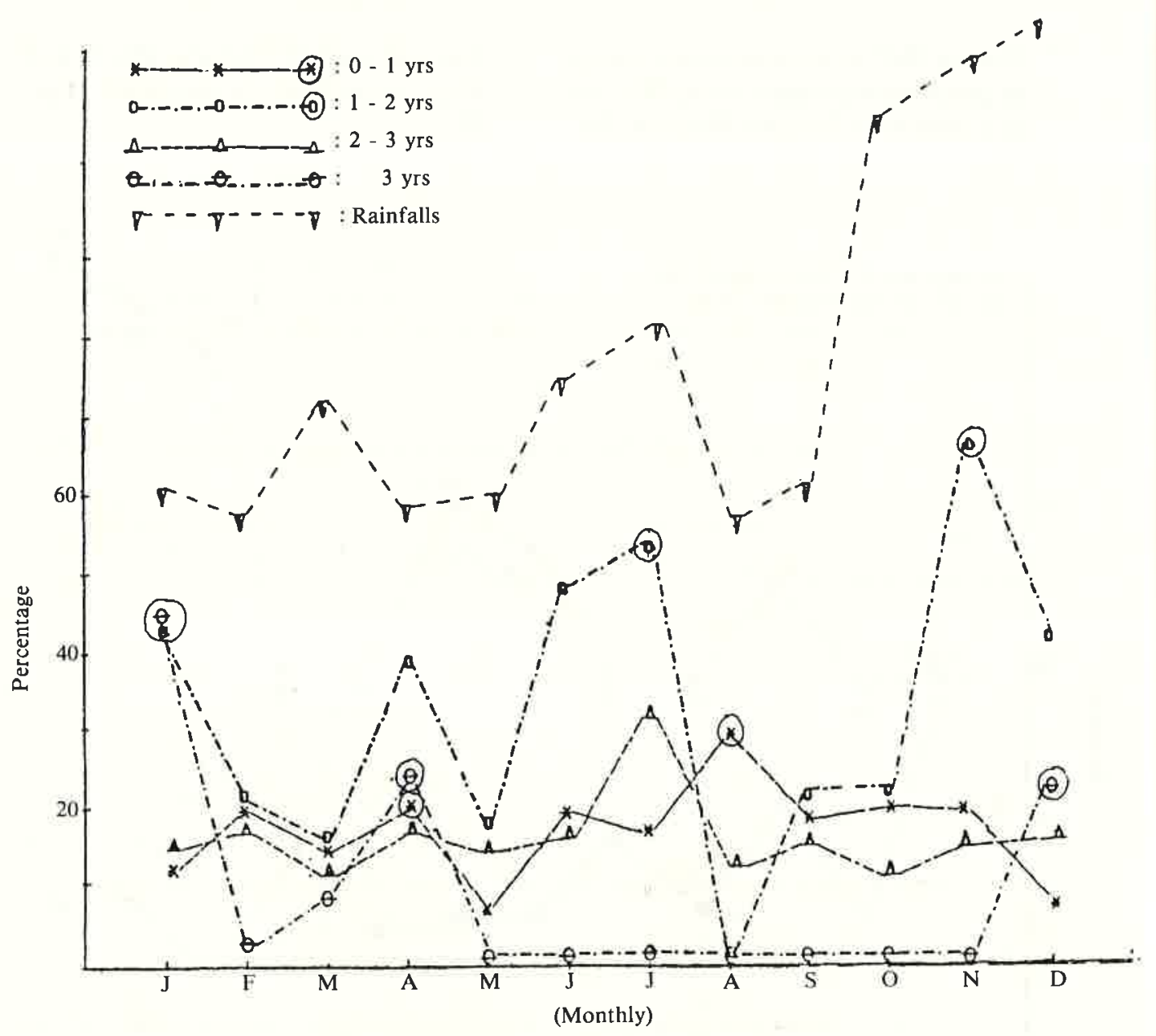

Fig. 4 : Percentage of Hospitalized cases of gastroenteritis at the Pediatric OPC Pirngadi Hospital, Medan, during 1982 according to the age groups and the rainfalls

January, April and December i.e. $45 \%, 25 \%$ and $25 \%$, respectively; (d) Age group older than 3 years, in July and November, i.e. $57.10 \%$ and $66.70 \%$ respectively; (e) There were no relationship between percentage of hospitalization and rainfalls (Fig. 4).

\section{Discussion}

1. The incidence rate of gastroenteritis in infants and children at the OPC for sick children of Pirngadi Hospital, Medan, Department of Child Health, School of Medicine, University of North Sumatera during year 1982 was $8.10 \%$. This rate was the same as the results found by previous authors in some OPC of several Hospitals in Medan, namely ranging from 7 to $15 \%$. (Hamid et al., 1982; Jo, 1965; Lubis el al., 1979; Nasution et al., 1982; Sinuhaji et al.,, 1984; Sufriar et al., 1982).

2. Gastroenteritis was mostly found in the age group of below two years (83.94\%); while patients under 1 year old were $62.68 \%$. Previous authors at the same place found the incidence rate of gastroenteritis in under 1 year old ranging from 46.64 to $62.68 \%$. (Lubis et al., 1979; Nasution et äl., 1982). Other authors from different centers also found more or less same results (Chai et al., 1969; Morley, 1979; Rowland, 1978).

3. Of the 1057 under fives with gastroenteritis, $36.22 \%$ were also suffering from malnutrition. Previously, some authors at the same place found it ranging from 11.68 to $44.76 \%$ (Hamid et al., 1982; Lubis et al., 1985; Marbun et al., 1984; Nasution et al., 1982; Sinuhaji et al., 1984; Sufriar et al., 1982), see Table 9.

Table 9 : Percentage of malnutrition in children with gastroenteritis in Pirngadi Hospital Medan during $1979-1983$

\begin{tabular}{|c|c|c|c|c|c|}
\hline Author & $\begin{array}{l}\text { G.E. } \\
\text { Patient }\end{array}$ & Year & Method & $\begin{array}{l}\text { Number of } \\
\text { malnourish }\end{array}$ & $\%$ \\
\hline Hamid et al., 1982 & Hospitalized & $1979-1981$ & Gomez & 826 & 22.45 \\
\hline Sufriar et al., 1982 & Hospitalized & $\begin{array}{c}\text { June - Dec } \\
1981\end{array}$ & Mc. Latam & 86 & 11.86 \\
\hline Nasution et al., 1982 & Hospitalized & $\begin{array}{c}\text { Jan - June } \\
1982\end{array}$ & Gomez & - & 16.3 \\
\hline Marbun et al., 1984 & Hospitalized & 1982 & KMS & 168 & 20.74 \\
\hline Author & OPC & 1982 & KMS & 383 & 32.30 \\
\hline Sinuhaji el al., 1984 & OPC & 1983 & KMS & 461 & 44.76 \\
\hline Lubis et al., 1985 & OPC & $1981-1982$ & KMS & 759 & 16.18 \\
\hline
\end{tabular}

Gastroenteritis and malnutrition are two conditions that influence each other. Gastroenteritis often results in anorexia and malabsorbtion that leads to malnutrition. Malnutrition results in disturbances of hos defence mechanism, intestinal function and intestinal flora thus predisposing to enteritis (Rowland, 1980). Other authors found that almost half of the cases with gastroenteritis were accompanied by malnutrition (Gracey, 1978). 
4. Of the 1246 attendants with gastroenteritis, in 370 the $\mathrm{Hb}$-levels were examined, revealing $50 \%$ to be suffering from anemia. Other authors found lower numbers (Gracey, 1978, Marbun et al., 1984) while at the same place other workers also found the same results (Sinuhaji et al., 1984).

5. Of the 1246 attendants with gastroenteritis, $213(17.07 \%)$ were hospitalized. Others authors found results ranging from 10 to $30 \%$ depending on the socio-economic state of the patients (Chai et al., 1969). The highest percentage of hospitalized patients was in the age group of older than 3 years; other authors at the same place found also the similar results (Sinuhaji et al., 1984)

6. Of the total attendants with gastro enteritis, only $28.90 \%$ had received rehydration solution. A similar result was also reported by other workers i.e. $35.90 \%$ (Sinuhaji et al., 1984). Only in 23 cases $(1.84 \%)$ the diarrhea lasted longer than 7 days. Other authors a

\section{Conclusions}

1. The percentage of gastroenteritis at the Pediatric OPC of Pirngadi Hospital, Medan during 1982 was $8.10 \%$ of total attendants.

2. The largest number and highest percentage of attendants with gastroenteritis were in January, April and May.

3. Most of the attendants with gastroenteritis were in the age group of under 2 years $(83.94 \%)$.

4. The highest percentage of under five patients with gastroenteritis who also suffered from malnutrition was in the age group of 1 to 2 years $(70.75 \%)$.

5. The percentage of hospitalized patients with gastroenteritis was $17.07 \%$. The highest percentage was in the age group of older than 3 years. In the age of under 1 year, most hospitalized patients were in the age group below 1 the same place reported results ranging from 0.96 to $5.9 \%$. At other centers authors found results ranging from 7.13 to $15.16 \%$ (Munir, 1985, Soeparto, 1985, Wiadnyana et al., 1982).

7. Of the 1110 patients with gastroenteritis attendants the Pediatric OPC of Pirngadi Hospital during 1982, most of them (996) had the episode of diarrhea one time per-year; in 94 patients it occurred two times; in 18 patients three times and in 2 patients four times per-year. Other workers had reported the episode of diarrhea 1 to 3 times per-year in groups of low socio-economic state and the episode 1 time peryear in the groups of higher socioeconomic state (Chai et al., 1969).

8. In this study no relationship could be seen between rainfalls and the incidence of gastroenteritis, neither did between raintalls and the number of nospitalized cases (Lubis et al., 1979, Nasution et al., 1981, Sinuhaji et al., 1984).

month and 10 to 11 months, namely $38.63 \%$ and $28.07 \%$, respectively.

6. Of 370 patients with gastroenteritis, $50 \%$ were suffering from anemia. The highest percentage was found in the under 1 year old $(67.02 \%)$.

7. The use of oral rehydration solution was still low (28.90\%).

8. Prolonged diarrhea was found only in 23 cases $(1.85 \%)$.

9. Out of the 1110 patients with gastroenteritis, the frequency of the episode of diarrhea per-year was one time in $89.73 \%$; two times in $8.45 \%$; three times in $1.62 \%$ and four times in $0.18 \%$.

10. No relationship could be seen between rainfalls and the percentage of hospitalized cases of gastroenteritis.
REFERENCES

BISHOP: Searching for viruses, Diarrhea Dialogue, issue No. 14. pp 9 August 1985.

2. Dep-Kes R.I.: Hasil Lokakarya Antropometri gizi Dep-Kes R.I. 1975.

3. CHAl, OP; KALRALS JAISWAC, VN Epidemiology of diarrhea in infancy and preschool children in rural community near Delhi. Indian Pediatric $6: 263-271$ (1969)

4. GRACEY, M; The problem of diarrheal disease in children. Pediatr. Indones., $18: 1-5$ (1978).

5. HAMID, N.; LUBIS, H.; SUTANTO, AH. SIREGAR, H.: Gastroenteritis di Bagian Ilmu Kesehatan anak FK USU/RS DR Pirngadi Medan. Kumpulan Naskah PIB BKGAI VIII Semarang, hal. 208 - 217 (1982)

6. JO, K.T.: Sehitar Kesejahteraan Anak. Pidato Pengukuhan pada peresmian jabatan Guru Besar tetap, Medan 18 Juni 1965

7. LANZKOWSKY, PL.; KARAYALCIN, G. MILLER, F.: LANE, BP.: Disacharidases values in iron deficiency infants. J. Pediat. 4 605-607 (1985)

8. LUBIS, Z: SINUHAJL, AB.: SEBAYANG, T. LUBIS, M.; BARUS, N.; SUTANTO, AH. Variabel yang mempengaruhi lama penyembuhan mencret pada bayi. Kumpulan makalah PIB BKGAl IX Palembang, hal. 287-294 (1984).

9. LUBIS, C.P.; RANGKUTY, S.M.; SIREGAR Z.; SUTANTO, A.H.; SIREGAR, H.: Kejadian muntah mencret pada bayi dan anak di Poliklinik Bagian Anak RSPM/Bagian Ilmu Kesehatan Anak FK USU 1967 - 1977. Kumpulan an Anak FK USU 1967 - 1977. Kumpulan makalah PIB

10. LUBIS, H.; SINAGA, J.; KARO-KARO, M. SAAT, R.; TARIGAN, SY.: Malnourished children (A study of parents status). Pediatr. Indones. $25: 112-117$ (1985)

11. MARBUN, M.D.; SINUHAJI, A.B.; SEBAYANG, T.; DAULAY, H.R.M.; SUSANTO, A.H.: Gambaran penderita gastroenteritis di Bagian Ilmu Kesehatan Anak RS DR Pirngad Bagian Ilmu Kesehatan Anak RS DR Pirngadi
Medan 1982. Kumpulan Naskah PIB BKGAI IX Medan 1982. Kumpulan Naskah PIB

Palembang, hal. 191-205 (1984).
MARWOTO, C.W. ABDULSALAM, M.;

2. MARWOTO, C.W.; ABDULSALAM, M
MARKUM, A.H.; MUSLICHAN, M.Z.; WA HIDIYAT, I.: Prevalensi kekurangan besi pada anak. Naskah Simposium dan Kuliah Tamu Kongres Nasional PHTDI III Bandung, hal. 67-76 (1980)

13. MORLEY, D.: Prioritas Pediatri di Negara Sedang Berkembang, Edisi Bahasa Indonesia. Penerbit Yayasan Essensia Medika, Yogyakarta, hal. 203-214 (1979).
MUNIR, M.: Determinant of chronic diarrhea in infant in Manado. Pediatr. Indones. 25 : 23-32 (1985)

5. NASUTION, I.K.; SUFRIAR, B.; SUTANTO, A.H.: Morbilli dengan gastroenteritis pada bayi dan anak. Kumpulan Naskah PIB BKGAI VIII Semarang, hal. 453-459 (1982).

16. NASUTION, M.A.; LUBIS, H.; HARAHAP, E S.; LUBIS, C.P.; SUTANTO, A.H.: Muntah ES.iLUBIS, C.P.; SUTANTO, A.H.: Mur Anak RS DR Pirngadi Medan/Bagian Ulmu KeAnaton A Pra FK USU 1978 - 1979. Tela disehatan Anak FK USU 1978 - 1979. Telah diaiukan pada Konika V Medan 16-18 Juni (1981). ROWLAND. M.G.M.: Bacterial contamination $21: 136-138$ (1978).

8. ROWLAND, M.G.M. Interaction between malnutrition and diarrhea: Etiological consideration in: Acute enteric infection in children, new aspect of treatment and prevention. Proc of Nebel Conference 3 (1980).

19. SINUHAJI, A.B.; DAULAY, HRM.; SEBA YANG, T.; FUAD ARSYAD.; SUTANTO A.H.: Gambaran gastroenteritis pada Poliklinik Anak Sakit Bagian Ilmu Kesehatan Anak FK USU/RS DR Pirngadi Medan 1983. Kumpulan ASU/RS DR Pi makalah PIB BKGAI IX Palembang, hal. 219-231 (1984)

20. SOEPARTO, P : Clinical pattern of chronic infantile diarrhea in Indonesia. Pediatr. Indones. 25 : 13-21 (1985).

21. SUMANTRI, A.G.; SUDIGBIA, I.; WIJAYA Iron deficiency anemia among Indonesian childien. Pediatr. Indones. 24 : 28-42 (1984).

22. SUFRIAR, B.; NASUTION, I.K.; SIREGAR H.; SUTANTO, A.H.: Gastroenteritis pada bay dan anak dengan kekurangan kalori protein. Kumpulan Náskah PIB BKGAI VIII Semarang hal. 453-459 (1982).

23. SUHARYONO, D.; ISMADI, S.D.; SUDAR DJ. ROHDE, J E. Kontaminasi dan pengenceran susu botol di daerah Yogyakarta. Berita BKGAI Th 3, Juli - Agussus, hal. 13 (1978). BKGAI Thn 3, JUL - Agus, TJK, MANOEROENG, S.M.; JO, K.T.: Buku Kumpulan Naskah KONIKA I Semarang, hal. 203-213 (1968)

25. TUMBELAKA, W.A.F.J.: Morbiditas dan Mortalitas diarrhea. Kumpulan Naskah PIB BKGA VI Ujung Pandang, hal. 42-51 (1979).

26. WIADNYANA, S; RIDWAN, MS.; HARDIANTHO, M. SOEPARNO, P : A clinical profile of acule infantile gantroenteritis. A sudy of 142 cases. Kumpulan Naskah PIB BKGA VIII Semarang, hal. 676-688 (1982). 